\title{
Monikulttuurisuus ulottumaan myös maaseudulle
}

Koti maalla. Käsikirja maahanmuutosta.

Maahenki 2010. 110 sivua.

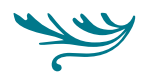

MAASEUDUN SIVISTYSLIITTO toteutti vuosina 2008-2010 Pohjois-Pohjanmaan 12 kunnan kanssa Muutoksessa mukana -monikulttuurisuushankkeen. Kuntien kanssa järjestettiin koulutusta virkamiehille ja poliittisille päättäjille ja etsittiin yhdessä jouhevia paikallisia ratkaisuja.

Hankkeen tuotoksista ilmestyi viime syksynä maahan- ja maallemuuton käsikirja. Se koostuu asiantuntijakirjoituksista, uussuomalaisten tarinoista sekä maahanmuuton perustietopaketista.

Mukana olleet kunnat eroavat toisistaan paljon. Yhteistä kuitenkin on, että maaseudun väestö vähenee ja vanhenee. Tekeviä käsiä ja osaajia tarvitaan alkutuotannosta vanhusten hoivakoteihin ja terveyskeskuksiin. Yhdessä kunnassa mietitään vastaanottokeskuksen palveluja, toisessa etsitään asuntoja töihin tuleville, maalaiskunnissa asuminen kun perustuu lähes kokonaan omistusasumiseen. Yksi kunta haluaa harjoittaa valikoivaa maahanmuuttopolitiikkaa ja toinen on avannut ovensa tulijoille.

Helsingin yliopiston Ruraliainstituutin vanhempi tutkija Antti Saartenoja käsittelee artikkelissaan erilaista kokemista maaseudusta tilana, ulkopuolisuutta ja toiseutta sekä kotouttamispolitiikkaa maaseudun kannalta. Allianssin moni- kulttuurisuus- ja vähemmistöasioiden suunnittelusihteeri Mirella Huttunen kirjoittaa oivaltavasti kotouttamisen kaksisuuntaisuudesta.

Kirjassa oman lyhyen tarinansa kertovat kymmenen pohjoispohjalaista uudisasukasta ovat yksimielisyydessään suorastaan ruusuisen tyytyväistä. Useimmat heistä ovat entisen Neuvostoliiton alueelta Tšetšeniasta Vienaan. Muuton syytkin vaihtelevat rakkaussuhteesta pakolaisuuteen.

Joko kertomuksista on jätetty pois rasistiset kokemukset ja kotiikävä tai sitten olemme ystävällisempiä ja ennakkoluulottomampia kuin yleinen julkipuhe antaa ymmärtää. Ehkä maahanmuuttajat ovat oppineet väistämään ikäviä tilanteita. Maahan muuttaneet kiittävät uuden kotimaan turvallisuutta, rauhallisuutta, tasaarvoa, virkamiesten ja ihmisten luotettavuutta, mielipidevapautta, luontoa ja kaupunkiympäristön viihtyisyyttä. Tekee myös mieli uskoa, sillä kertojilla on vertailukohde korruptoituneisiin, epädemokraattisiin ja fyysisesti turvattomiin kulttuureihin.

Kertojat ovat asuneet paikkakunnilla 3-12 vuotta. Jokainen on myös työllistynyt.

Venäjän Karjalasta Raaheen muuttaneen Oxinan havainnon mukaan maahanmuuttaja saattaa kokea suomalaisen kulttuurin tärkeämpänä kuin moni kantasuomalainen.

Kaikki ovat kokeneet mahdollisuuksien avautuvan oman aktiivisuuden kautta. Sosiaalisten verkostojen merkitys on keskeinen. Tulevaisuuteen katsovissa kansalaisjärjestöissä mietitäänkin, miten sisäänlämpiävyys väistyisi taaemmaksi. Epävirallisten yhteyksien kautta muuttaja oppii kielen, ystävystyy ja saa jalansijaa yhteiskuntaan ja samalla kantaväestökin ovat monella tapaa saavana osapuolena.

Käsikirja on nähtävä asennekasvatuksena. Sitä tukevat niin maahan muuttaneiden puheenvuorot kuin kirjan innostava kuvitus. Kirja ei puutu kausityön ilmeisiin epäkohtiin. Väärinkohteluun, saati sitten työvoiman rikolliseen hyväksikäyttöön on puututtava ja niiden varalle muuttajia valistettava. Mutta se ei ole tämän käsikirjan tehtävä, koulutuksen ja kotouttamisen kylläkin.

Kirja on tarkoitettu kuntien johdolle ja luottamushenkilöille sekä maahanmuuttajia työssään kohtaaville.

http://www.msl.fi/msl/muuttiedostot/Koti\%20maalla\%20web.pdf

Anneli Kajanto 